\title{
Entrepreneurial Plights in Prevailing Socio-Economic Condition of Divorced Women in Sylhet City
}

\author{
Samiur Rashid Chowdhury \\ Senior Lecturer, Department of Law, Sylhet International University \\ email-samiur.rashid@yahoo.com
}

\begin{abstract}
Abdul Latif
Associate Professor, Department of Business Administration, Sylhet International University email-novalatif@gmail.com
\end{abstract}

\begin{abstract}
Like other contracts, the lasting of social contract of marriage depends on the understanding, adjustment and obligations of both the parties. The failure in establishing those creates conflicts and long lasting conflicts lead to dissolution of contract that creates a new product- 'divorced women' in the society. These women have to plight in the society without the necessary supports from different corners. This study attempts to find out the reasons and consequences of such dissolutions and tries to find out the remedies to minimize the sufferings of divorced women. This descriptive analytical research is conducted by questionnaire method to collect primary data from divorced women of Sylhet city. The sampling was designed in random probabilistic method. The findings highlighted the reasons on misunderstanding, failure in adjustment and discharge obligations as the causes of separation. The separation process is not smooth and justified to the unfortunate women. The realization of their dues is not justified also. The utilization of the fund for profit generating businesses, the support to build up such enterprises and the management of these organizations are not effective because of gender biased social environment. The social and le gal supports should be ensured for such destitute women to make them self-sufficient and materialize a prestigious future for them and their kids.
\end{abstract}

Keywords: Social Contract, Marriage, Divorce, Management of post divorced lives

\section{INTRODUCTION}

Marriage is a legal and social relationship between men and women. Through having children to grow those up marriage becomes relatively stable relationship in society. Men and women live together with mutual understanding for longer period expected up to the death. But lack of understanding sometimes brings divorce that separate men from women and leads to the separated life for both or arrange other relationship with different persons. Divorce is practiced in all the societies with variation in the implementation. The rate of divorce in some countries is severely high where marital bondage is not strong. Divorce may be held on certain ground in the countries where marital bondage is high. Conflict in marriage is common and sometimes inevitably long lasting that leads to the ultimate dissolution of the marriage by divorce. Due to lack of adjustment with each other in the life style, eating habit, personal taste and ways of thinking and behaving, divorce is inevitable. It is the solution of conflict and free both person from one another but create problems in one's day to day life. It crates social and economic problem for at least in the life of one person as well as for children. Is Asia, particularly in Bangladesh, problems of divorce are more severe for women than for men because of the socio-cultural circumstances where women are not allowed to lead their lives independently. There are several issues of divorced women like maintenance, custody of minor children, future life, sexual and social need etc. They are not provided the social, economic and social support from the family or society. In Bangladesh, most women are dependent on their male counterpart for fulfillment of their basic needs. So they face lot of problems in their divorced lives. Various forms of divorce are practiced in Muslims of Bangladesh who are the majority. It can be practiced in the form of i. divorced by husbands' ii. Divorced by wife through a. delegation of divorce, b. Redemption, iii. Divorced by mutual consent and iv. Dissolution by judicial process. Marriages are breaking down in Bangladesh increasingly and sometimes that process does not follow the marriage and divorce related laws. Illegal divorce is more than the legal divorce in Bangladesh 
and the weaker parties generally do not seek justice from the law because of economic and social reason. The divorced women have to do plight for their survival.

The researchers seek to find the legal process of divorce and plight of divorced women for their survivals.

\section{LITERATURE REVIEW}

Marriage is a legal relationship between men and women. It is the erotic sexual relationship derived from marital right and duties (Velde 1976). The social life is molded in great extend by social institution marriage in every society (Johnson 1970). Most of the people believe that family and sexual relationship should be within legal marriage. Adaptability is essential to maintain the relationship by adjusting successfully between the conflicting personalities. Lack of adaptability brings break down of marriage (Fonseca 1966). It is found that middle class people have sufficient knowledge about dower, dowry and marriage registration but is absent on lower class people. Majority of the women argued that dower and marriage registration is important to strengthen the marriage bondage (Rahman 1996). Rahman (1997) studies found that peaceful conjugal life can prevent separation, family disorganization and divorce. Age, age gap, social consistency between couples and financial solvency before marriages etc. are to be considered to establish peaceful conjugal life. It is also found that a majority of women did not get the dower after long years of marriage and even they do not know the exact amount of dower and do not have the marriage registration deed (Nasir and Pervin 1996). Zaman (1990) found some causes of divorce as under aged marriage, lack of happiness of husbands, mother in laws, frustration of husbands, illicit sexual relation, dowry, chronic disease of wives, venereal diseases and failure of husbands in satisfying their wives sexually etc. Sometimes the relationship is disturbed by mistrust and conflict. Such conflict may leads to divorce. Shahidullah (1979) found infertility and sub-fecundity in the first two years of marriage is directly related to the high proportion of early divorce. Sheikh (1998) found that Propensity to divorce declined significantly with an increase in the number of children. Relationship of education and divorce is insignificant and negative. Rate of divorce is lower in businessmen and agricultural labors than among farmers. It is higher in love matches than arranged one. The differences in ages also influence the rate of divorce. The rate of divorce is also found higher in first three years of marriage than longer duration. The low socio-economic status of spouse, illiteracy and early marriage increase the odds of divorce (Alam et al 2000). It's a social phenomenon like marriage and sanctioned arrangement to terminate the marriage formally and dissolve the family group (Bertrand 1967). Divorce brings emotional shock, social stigma and economic problem for at least one party as well as for children (Bertrand 1976). There are various forms of dissolution of Muslim marriage; a. divorce by husbands by means of talak (release from a knot) b. divorce by the wife by $i$. delegation of divorce and ii. Redemption (same as men's right of talak) c. divorce by mutual consent or mutual freeing and d. dissolution by judicial process (Ahmed 2007). But when a woman seek divorce she is considered as irresponsible, not being a good mother and being selfish (Srivastava 2002). Women headed families due to divorce and death of spouse are found facing the problems like poverty and economic insecurity, social constraints, political powerlessness and the problems faced by second generations (Hossain and Huda 1995). Momen et al (1995) found that after marital disruption some women live in single status, some are dependent on others. The social support system helped some to recover their rights and on the whole it cannot play effective role in case of abandonment. The dower is recovered partially or fully in case of divorce. Choudhury (1988) found trauma as a result of divorce. Dorga (1999) found emotional and behavioral problems in children due to divorce. Pothen (1986) found fewer problems in men than women after divorce due to higher remarriage rate of men. It resulted in acute emotional problems in women. Marwaliker et al. (2001) found that due to lack of social security and strong social customs, women have to live with their parents after divorce.

\section{OBJECTIVES}

The main objective of the research is to examine the socio-economic condition of divorced women and their plights for survivals. The specific objectives are:

- To examine the profile of divorced women.

- To examine the reasons of separations 
- To examine the separation process and recovery of rights

- To examine the social support to these women

- To examine their efforts to build up enterprises and careers.

\section{ReSEARCH Methodology}

Research Design: This is a descriptive analytical research conducted by empirical analysis. The research was designed to conduct by survey method through questionnaire technique.

Sampling design: The research was conducted by random sampling technique to get the representation of divorced women.

Reliability and Validity: The reliability of questionnaire was established by checking the Cronbatch Alpha (.68) and the validity by the positive opinion of senior researchers on Research Design: This is a descriptive analytical research conducted by empirical analysis. The research was designed to conduct by survey method through questionnaire technique.

Sampling design: The research was conducted by stratified sampling technique to get the representation of policyholders, knowledgeable persons from different professions.

Reliability and Validity: The reliability of questionnaire was established by checking the Cronbatch alpha (.68) and the validity by the positive opinion of senior researchers on social problem.

Data Collection: The data were collected from 175 respondents from April to August 2015 by door to door method. The sample size was determined by using the formula:

Data Analysis: the collected data was duly processed by SPSS 19 and analyzed by the use of percentile, simple statistical method, frequency analysis and percentage etc.

\section{FindingS}

The profile of the divorced women is summarized in the following table.

Table1. Profile of respondent divorced women of Sylhet:

\begin{tabular}{|l|l|l|l|l|}
\hline & \multicolumn{3}{|c|}{ Divorced Wife } & \multicolumn{2}{l|}{ Husbands' of divorced wife } \\
\hline Occupation (Pre-marriage stage) & Frequency & Percentage & Frequency & Percentage \\
\hline a. Job- & & & & \\
\hline i) Junior Level & 54 & 31 & 52 & 30 \\
\hline ii) Mid Level & 42 & 24 & 44 & 25 \\
\hline iii) Senior Level & 22 & 13 & 20 & 12 \\
\hline b. Own Business- & & & & \\
\hline i) Small & & & 13 & 7 \\
\hline ii) Medium & 11 & 6 & 5 & 3 \\
\hline iii) Big & 3 & 2 & 41 & 23 \\
\hline c. Unemployed/Dependant & 43 & 24 & & \\
\hline & 175 & 100 & 175 & 100 \\
\hline Education & & & & \\
\hline a. Never gone to the school. & 37 & 21 & & \\
\hline b. Below primary level. & 00 & 00 & & \\
\hline c. Below SSC. & 21 & 12 & & \\
\hline d. Below HSC. & 25 & 14 & & \\
\hline e. Graduate. & 8 & 5 & & \\
\hline f. Post-graduate. & 17 & 10 & & \\
\hline & 67 & 38 & & \\
\hline Family Income & & & & \\
\hline a. Below 5000 tk & & & & \\
\hline b. 5000-10000 tk & 97 & 56 & & \\
\hline c. 10000-20000 tk & 53 & 30 & & \\
\hline d. Above 20000 tk & 25 & 14 & & \\
\hline Parents home of wife & & & & \\
\hline a. Urban & 45 & 26 & 37 & \\
\hline b. Rural & 87 & 89 & 82 & \\
\hline c. Semi-urban & 43 & 60 & 56 & \\
\hline
\end{tabular}




\begin{tabular}{|l|l|l|l|l|}
\hline \hline Duration of marriage & & & & \\
\hline a. Less than 1 Year & 18 & 10 & & \\
\hline b. 1 Year- 2 Year & 36 & 21 & & \\
\hline c. 2 Year- 5 Year & 79 & 45 & & \\
\hline d. More than 5 Year & 42 & 24 & & \\
\hline Type of marriage & & & & \\
\hline a. Love marriage with family consent & 28 & 16 & & \\
\hline b. Love marriage without family consent & 30 & 17 & & \\
\hline c. Arranged marriage & 117 & 67 & & \\
\hline d. Other & & & & \\
\hline
\end{tabular}

Source: Field Survey

From the profile of the divorced women, it is found that divorce held more in lower level of employment of both men and women. It is help in lower income family and within less educated couple. The people of rural areas face higher rate of divorce than the people of urban or semi-urban areas. More separations are held within 2-5 years of marriage and in the love marriage than in the arranged marriage because of higher expectations in love marriage.

The causes of separation are tabulated below:

Table2. Causes of separation:

\begin{tabular}{|l|l|l|l|}
\hline Criteria & Specific Causes & Number & Frequency (\%) \\
\hline Liking & Perception of/actual dislike by husband & 23 & 13 \\
\hline Ability & Physical/sexual inability of wife & & \\
\hline Behavior & Character of husbands & 9 & 5 \\
\hline & Misbehavior of husband & 9 & 5 \\
\hline & Physical/mental Torture by husband & 36 & 20 \\
\hline External reasons & Conspiracy of in-laws & & \\
\hline & Financial Reason & 98 & 57 \\
\hline
\end{tabular}

Source: Field Survey

The reason of separation as mentioned by the women respondents may be one sided. But it reflects the truth though it is not checked by counter response. The reasons mentioned by the wives can be categorized into liking, ability, behavior and like. Majority of the women (57\%) mentioned financial reason as the cause of separation between them. The greed for dowry, financial inability of the husbands, possibility of getting benefits from second marriage etc. are the financial reasons of separation. The behavioral reason is placed in second position in the list of causes of separation. A significant portion (30\%) mentioned behavioral problem of the husbands as the reason for separation. Among the behavioral reason, the physical/mental torture by the husbands places in the first position $(20 \%)$ that is followed by character of husbands $(5 \%)$ and misbehavior of them (5\%). Nobody mentioned the physical/ sexual inability of husbands or wives as a reason for separation. It may because of conservativeness of the society though the researchers' perception about that reason is positive like other research works. The disliking of husbands is mentioned by the wives (13\%) as one of the reasons of separation. The researchers also perceive that the disliking of wives may be another actual cause of separation though the women did not mentioned it.

Number of Children at the time of separation:

\begin{tabular}{|l|l|l|l|}
\hline Age of Kids & Of women & Percent & Average Number of Kids per Women \\
\hline $0-5$ Years & 93 & 53.14 & 1.2 \\
\hline $5-10$ years & 64 & 36.57 & 1.7 \\
\hline $10-15$ years & 15 & 8.57 & 1.75 \\
\hline 15 -above & 3 & 1.71 & 2.1 \\
\hline Total & 175 & 100.00 & \\
\hline
\end{tabular}

From the literature survey it was found that the rate of divorce is high at first two or three years of marriage and the higher number of kids or elder aged kids reduce the rate of divorce. This study also reiterate the provision of divorce fluctuate depending on the number of kids and duration of marriage. Around 53\% women experienced divorce when they have 0-5 year old kids on an average 1.2 per woman. The rate of divorce decreases in case of women with 5-10 years age children with an average 
of 1.7 per women. It is more decreased in case of women with higher aged children. So the higher number of children reduces the risk of divorce among women.

The process of separation is mentioned in Table 3:

Table3. Process of separation

\begin{tabular}{|l|l|l|l|}
\hline \multirow{3}{*}{ Apply to } & & Number & Percent \\
\hline \multirow{3}{*}{$\begin{array}{l}\text { Step taken by the authority } \\
\text { for reconciliation }\end{array}$} & Applied to the Chairman/Representative & 82 & 47 \\
\cline { 2 - 4 } & Applied to the Court & 95 & 53 \\
\cline { 2 - 4 } & Fuccessful & 13 & 7 \\
\cline { 2 - 4 } & No initiatives & 157 & 90 \\
\hline Realization of dower & Applied to the Chairman/Representative & 5 & 3 \\
\cline { 2 - 4 } & Applied to the Court & 57 & 33 \\
\hline Realization of dower & $50 \%-75 \%$ & 118 & 67 \\
\cline { 2 - 4 } & $25 \%-50 \%$ & 33 & 19 \\
\cline { 2 - 4 } & Below 25\% & 103 & 52 \\
\hline
\end{tabular}

Source: Field Survey

The social and legal process may be used for the dissolution of the contract of marriage. The social process is less costly, easier and less time consuming. But the failure of the social process or lack of confidence in social process, the parties of the contract use the courts for their intended separation. The stronger social process reduces the importance of courts and legal process. But it is found that use the social and legal process in the case of separation is equal. It indicates the sufferings of the women in their disturbed conjugal life become more pitiful in the time of separation also.

\section{Step for reconciliation}

Reconciliation is the process used in social and legal process in order to restore the relationship by reducing the elements of conflict through mediation. But the success rate of this process is unfortunately very low. Only $7 \%$ of the reconciliation process becomes successful in restoring the relationship by reducing conflicts or misunderstandings.

Though right of dower is protected by religion and laws of the country, the realization process is not smooth in any case. Most of the women (67\%) have to go in legal process by the court to recover the money. The rest recover that money by comparatively easy and less costly process of using mediator, representative or local chairman for that purpose.

By using the legal process and social process the realization of dower is initiated. But it is unfortunate that deduction in dower amount is held in all the process. Most of the women (52\%) had to be satisfied with only $25-50 \%$ realization. Around $50 \%$ of the rest got $50-75 \%$ and another $50 \%$ got below $25 \%$. Thus the fates of destitute women become more risky in the dissolution process also. Society cannot ensure their right of getting dower fully in case of dissolution.

Table4. Maintenance Cost for Livelihood

\begin{tabular}{|c|c|c|c|}
\hline & \multicolumn{3}{|l|}{ Cost of livelihood } \\
\hline & Percentage of sufficiency & Number & Frequency $(\%)$ \\
\hline \multirow[t]{3}{*}{ Sufficiency of maintenance cost } & Below 25\% & 163 & 93 \\
\hline & $25-50 \%$ & 8 & 5 \\
\hline & $50-75 \%$ & 4 & 2 \\
\hline \multirow{3}{*}{$\begin{array}{l}\text { Duration of Divorced wife's } \\
\text { maintenance }\end{array}$} & Below 1 year & 82 & 47 \\
\hline & $1-3$ years & 57 & 33 \\
\hline & $3-5$ years & 36 & 20 \\
\hline \multirow{3}{*}{$\begin{array}{l}\text { Action in case of unwillingness } \\
\text { to pay the dower and } \\
\text { maintenance of child and } \\
\text { divorcee }\end{array}$} & Legal action & 108 & 62 \\
\hline & Social pressure & 45 & 26 \\
\hline & Remained Silent & 22 & 12 \\
\hline
\end{tabular}

Source: Field Survey

The maintenance cost provided by the husbands is supposed to cover total expenses of divorced wife with the kids under 18. But it is found that $93 \%$ of the women got below $25 \%$ of the maintenance 
cost. This violation is held for influence of the husbands or financial inability of them as most of them start a new life with new bride and the cost of maintaining two families are harder for them.

Most of the divorced wives (47\%) are getting the maintenance cost up to one year only, $33 \%$ for 1-3 years and $20 \%$ for $3-5$ years. So the divorced women have to work hard for their survival in adverse environment.

There are provisions of legal action for non compliance with the existing rules. The social influence may be used in that purpose. But lack of social influence I most of the respondents (74\%) have to take either legal action or remain silent. It is found that $62 \%$ are intended to take legal action against the non compliant men in case of dower and maintenance. It is also found that $12 \%$ are intended to be silent in case of violation by the male counterparts.

Table5. Realization in case of non-payment

\begin{tabular}{|l|l|l|l|}
\hline & & Number & Frequency (\%) \\
\hline \multirow{2}{*}{$\begin{array}{l}\text { Result of action by courts or society in } \\
\text { realizing the dower and maintenance }\end{array}$} & Fully realized & & \\
\cline { 2 - 4 } & Partially Realized & 43 & 25 \\
\cline { 2 - 4 } & Process Continuing & 78 & 45 \\
\cline { 2 - 4 } & $0 \%$ realized & 54 & 20 \\
\hline \multirow{2}{*}{$\begin{array}{l}\text { Realization process of maintenance } \\
\text { costs }\end{array}$} & At a time & 12 & 7 \\
\cline { 2 - 4 } Realization process of dower & By installment & 163 & 93 \\
\hline & By installment & 145 & 17 \\
\cline { 2 - 4 } & At a time & 30 & \\
\hline
\end{tabular}

Source: Field Survey

Though there are sufficient provisions in laws for recovering the dower and maintenance cost from the husbands, the realizations of such dues is not possible for local influences, economic reason and other factors. It is found that no one got the money as fully realized, 25\% got partial amount and 20\% failed to realize any amount. Forty five per cent mentioned that the process of recovery is continuing and the fate is uncertain. It is assumed that the trend of recovery may continue in that case also.

The realization process of the maintenance amount is not helpful for these destitute women. Mentioning the financial limitations the husbands take the advantages of paying these amounts in installments. It is found that $93 \%$ realized the mentioned partial amount in installments and the rest $7 \%$ were lucky enough in collecting that amount at a time. It is almost same in case of dower. Seventeen percent realized that amount at a time.

Table6. Post Divorced Status

\begin{tabular}{|l|l|l|l|l|l|}
\hline Present occupation: & \multicolumn{3}{l|}{ Dependency } & Frequency & $(\%)$ \\
\hline Housewife after remarried & Frequency & $(\%)$ & & 6 & 3 \\
\hline Domestic help & 44 & 25 & On son' family & 6 & 8 \\
\hline Looking after inherited property & 36 & 21 & Brothers' family & 14 & 51 \\
\hline day labor & 18 & 10 & Parents' family & 90 & 13 \\
\hline Operating small business & 00 & 00 & Self Income & 22 & 25 \\
\hline Hotel/mess cook & 18 & 10 & Remarried & 44 & 94 \\
\hline Agricultural work & 36 & 20 & Total & 175 & \\
\hline Prestigious Profession & 23 & 14 & & & \\
\hline Total & 00 & 00 & & & \\
\hline
\end{tabular}

Source: Field Survey

It is found that most of the women after divorce are not leading any prestigious job except $45 \%$ who are supposed to be in better position. Of them, 25\% are remarried, $10 \%$ are looking after their inherited property and $10 \%$ are operating small businesses for their livelihood. Unfortunately, 55\% of them are working as domestic help, hotel/mess cook or agricultural work.

The major concern for divorced women is the shelter. In our social system, a woman must take shelter to men's family for her security. The parents' house is the major shelter for divorced women $(51 \%)$ though $25 \%$ get the shelter in new husbands' house because of remarries who are supposed to live better though there are also fears of mental pain by the members of new family. The matured and separated son and the earning brothers give shelter to some of the divorced women (13\% in total) and another $13 \%$ have managed their shelter by their own income (supposed to be in poor position). 
Table7. Problems of Divorced Women:

\begin{tabular}{|l|l|l|l|}
\hline \multirow{3}{*}{$\begin{array}{l}\text { Major personal problems of } \\
\text { divorce women }\end{array}$} & Victim of negligence in sheltered family & 28 & 16 \\
\cline { 2 - 4 } & Crisis of shelter & 42 & 24 \\
\cline { 2 - 4 } & Sufferings from loneliness & 49 & 28 \\
\cline { 2 - 4 } & Victim of sexual harassment by hoodlums & 21 & 12 \\
\cline { 2 - 4 } & Lack of Healthcare & 35 & 20 \\
\hline Improper Healthcare & Financial problems & 132 & 75 \\
\cline { 2 - 4 } & Negligence by the host & 43 & 25 \\
\hline Social Problems & Lack of safety \& Insecurity & 114 & 65 \\
\cline { 2 - 3 } & Problems in social or cultural programs & 35 & 20 \\
\cline { 2 - 3 } & Disturbance by local hoodlums & 26 & 15 \\
\hline
\end{tabular}

Source: Field Survey

The $25 \%$ lucky divorced women who are remarried are also suffering in different types of personal problem with the rest $75 \%$. The divorced women have mentioned their major problem as loneliness $(28 \%)$, crisis of shelter (24\%), lack of healthcare (20\%), victim of negligence in sheltered family (16\%) and most unfortunately victim of sexual harassment by hoodlums (12\%). The remarried women are also suffering for their accident in the form of negligence, healthcare and other. Almost all of the divorced women who are not remarried must have the problem of loneliness though $28 \%$ mentioned it as a major problem. Negligence is another problem that is supposed to attach with all the unfortunate women though $16 \%$ mentioned it as major problem. From the interview and observation the researchers inferred that all the divorced women are unfortunate as they are victim of almost all the mentioned problems. The crisis of shelter and security is the main cause of these problems.

The divorced women are suffering from improper healthcare as they perceive. The respondents identified two reasons for that problem. The financial problem may exist in most of the families of Bangladesh as it is a country of lower middle income economy. But the $25 \%$ of divorced women mentioned the problem of negligence to their health issue that is painful not only physically but also mentally.

Among the social problem most of the divorced women mentioned lack of safety and security as number one problem, Problems in participating social and cultural program as a divorced women as number two and disturbance by local hoodlums as number three problem. Thus the social lives of divorced women are disturbed in our society though the women are not only liable for their accidents.

Table8. Overall Financial, Mental and Social Position of Divorced Women

\begin{tabular}{|l|l|l|l|l|l|l|}
\hline & Better & Worse & \multicolumn{2}{l|}{ No Change } \\
\hline & Frequency & Percentage & Frequency & Percentage & Frequency & Percentage \\
\hline Financially better. & 52 & 30 & 123 & 70 & 00 & 00 \\
\hline Mentally better. & 65 & 37 & 63 & 36 & 47 & 27 \\
\hline Socially better. & 18 & 10 & 90 & 51 & 67 & 39 \\
\hline
\end{tabular}

Source: Field Survey

Though divorce free the disturbed men and women from their conflicting lives, the post divorced lives indicates no better position for most of the women in financially, mentally and socially. Financial position is supposed to be worse after divorce as in our country the working field is suitable for men and in practical it is proved as $70 \%$ of them mentioned their financial position become worse after separation. The social position is also supposed to be worse and it is proved by $51 \%$ of the women. Only mental position is supposed to be better because as liberty from conflicting lives. But is this study, the two conflicting consequences are found equal; $37 \%$ feel they are mentally better now and $36 \%$ feel their worse position and $27 \%$ feel no change in their mental position. It may because of the loneliness and other troubles from society.

Table9. Assistance from the GO,NGO and others

\begin{tabular}{|c|c|c|c|c|c|c|}
\hline & \multicolumn{2}{|c|}{ Govt. Contribution } & \multicolumn{2}{|c|}{$\begin{array}{l}\text { NGO or } \\
\text { organizational }\end{array}$} & \multicolumn{2}{|c|}{$\begin{array}{l}\text { Relatives' } \\
\text { Contribution }\end{array}$} \\
\hline & Number & $(\%)$ & Number & $(\%)$ & Number & $(\%)$ \\
\hline Getting regularly a negligible amount. & \multirow{5}{*}{$\begin{array}{l}\text { No } \\
\text { contribution } \\
\text { from the } \\
\text { government. }\end{array}$} & & & & & \\
\hline Getting irregularly a negligible amount. & & & 35 & 20 & & \\
\hline Got a small amount at a time. & & & & & 61 & 35 \\
\hline Got a considerable amount at a time. & & & 53 & 30 & & \\
\hline No help & & & 87 & 50 & 114 & 65 \\
\hline
\end{tabular}

Source: Field Survey 


\section{Samiur Rashid Chowdhury \& Abdul Latif}

As it is proved that the divorced women are facing financial problem severely as the society is not providing earning opportunities to women equally. So the social support is most important for these destitute women. In Bangladesh the financial supports can be derived from Govt., NGO or different organizations and or relatives/informal sources. It is found the respondents have not provided Govt. support in any form. The NGO or institutional supports are available for $50 \%$ of the respondents. Of them $30 \%$ got a considerable amount from different organizations at a time and $20 \%$ got a small amount of financial help in irregular basis. The neighbors and relatives support are available to only $35 \%$ of the women in small amount at a time and the rest $65 \%$ have not got any help from relatives or neighbors. So the contribution of the society towards destitute women is very insignificant and the women have to drive for their survivals individually in the unfavorable environment.

Table10. Assistance for Establishing Profit Generating Project:

\begin{tabular}{|c|c|c|c|c|}
\hline & & \multicolumn{3}{|l|}{ Source of capital } \\
\hline & & & Number & Frequency $(\%)$ \\
\hline \multirow{10}{*}{$\begin{array}{l}\text { Established profit } \\
\text { generating project } \\
\text { after separation }\end{array}$} & \multirow[t]{8}{*}{ Yes } & Dower/maintenance & 1 & 3 \\
\hline & & Inherited property & 6 & 20 \\
\hline & & Loan from bank or FI & 6 & 20 \\
\hline & & Informal Loan & 1 & 3 \\
\hline & & Assistance of NGO or other organization & 14 & 48 \\
\hline & & Assistance from Relatives & 1 & 3 \\
\hline & & Personal Savings & 1 & 3 \\
\hline & & Total & 30 & 17 \\
\hline & No & & 145 & 83 \\
\hline & & Total & 175 & 100 \\
\hline
\end{tabular}

Source: Field Survey

Of the destitute women, $17 \%$ of the women have started their profit generating business for their survival. Out of the 30 destitute women, $48 \%$ got assistance from NGO or other organization. $20 \%$ of them used their inherited property or loan from bank or other financial institutions. One of the destitute women used their dower/maintenance amount, informal loan, assistance from relatives and personal savings in their business. So it is found that in building profit generating business the role of assistance from NGO or other organization is prominent that of followed by use of inherited property and loan from bank or other financial institutions. The less use of dower indicates the difficulty in recovery of dower money by many of the destitute women.

Table11. Present Status of the Established Enterprise:

\begin{tabular}{|l|l|}
\hline & Frequency (\%) \\
\hline Unable to make profit. & 45 \\
\hline Became loosing concern and closed & 35 \\
\hline Suffering due to the shortage of fund. & 10 \\
\hline Running normally & 15 \\
\hline
\end{tabular}

Source: Field Survey

To examine the present status of the enterprises, it is found that $45 \%$ of the enterprises are unable to make profit, $35 \%$ became losing concern and closed, $10 \%$ are suffering from shortage of fund and $15 \%$ are running normally. So most of the firms are not running effectively may be because of shortage in financial resources or inability due to gender limitations.

Attitude of the employees, buyers and suppliers of own enterprise:

Table12. Condition of the Job/Carrier

\begin{tabular}{|l|l|l|}
\hline & Number & Frequency (\%) \\
\hline Lost job due to organization wound up/ It fall in problem. & 9 & 5 \\
\hline Got promoted after divorce & 18 & 10 \\
\hline No significant change after divorce. & 78 & 45 \\
\hline Left previous job due to personal cause & 35 & 20 \\
\hline Got better job. & 35 & 20 \\
\hline Total & 175 & 100 \\
\hline
\end{tabular}

Source: Field Survey 
The divorced women have to maintain their lives by small less prestigious jobs. The freedom from conflicting conjugal lives supposed to give someone opportunities to use their talents in their jobs and ensure progress in their lives. But mental deterioration deters somebody in utilizing their efforts because of their major accident in lives. So $45 \%$ are found in previous position in their job while $10 \%$ left job their personal cause. The position of $30 \%$ is found to be improved as $10 \%$ of them promoted after their separation and $20 \%$ of them got better position in their job.

Table13. Sentiment of the Organizational Environment after the Divorce

\begin{tabular}{|l|l|l|}
\hline & Number & Frequency (\%) \\
\hline Sympathetic and co-operative. & 9 & 5 \\
\hline Apathetic and non-cooperative. & 35 & 20 \\
\hline Pinching from colleagues. & 26 & 15 \\
\hline Positive attitude from the employer. & 14 & 8 \\
\hline Negative attitude from the employer. & 21 & 12 \\
\hline No change at all. & 70 & 40 \\
\hline
\end{tabular}

Source: Field Survey

Besides financial and physical support the destitute women need mental support from their neighbors and relatives. But the study showed no positive news in this regard. Most of the respondents noticed no change in the attitudes of their colleagues or bosses. Only $13 \%$ got sympathy and co-operative attitudes from their working environment. Of the rest, $47 \%$, some are getting apathetic but non cooperative attitudes (20\%), pinching from colleagues (15\%) and overall negative attitudes $(12 \%)$.

Table14. Willingness about Remarriage

\begin{tabular}{|l|l|l|}
\hline & Number & Frequency (\%) \\
\hline Willing to remarry but not expressing & 44 & 25 \\
\hline Willing but nobody come forward to marry & 52 & 30 \\
\hline Willing to remarry but nobody cooperating & 52 & 30 \\
\hline Willing but high demand of dowry by males & 8 & 5 \\
\hline Declined to remarry & 19 & 10 \\
\hline Total & 175 & 100 \\
\hline
\end{tabular}

Source: Field Survey

All women have the intention to live a conjugal life with her husband. This is also true for the divorced women. They never give up the will to remarry. Only $10 \%$ of the respondents gave up the will to remarry. The rest $90 \%$ are willing to remarry. Of them, $25 \%$ do not express their will, $30 \%$ get nobody to marry them and another $30 \%$ get no cooperation in their process of remarry and $5 \%$ failed because of high demand of dowry from willing men.

\section{Overall Discussion}

Separation in marriage is dissolution of social contract. As a social institution, marriage is the physical and mental relationship between two opposite gender person. The expectation from this contract is the product (children) and service (better relationship of trust and love). Lack of behavioral adjustment and fruitful physical relationship, greed (generally of husbands) and financial inability is the causes of dissolution of contract. The dissolution process may in held in social or legal environment. As the later is more costly, time killing and prestige hampering, the expectation on social process is supposed to be higher but lack of confidence on the ability of social process leads people to the legal process. It is found that half of the people have to use legal process for that purpose. The right of women in their conflicting conjugal lives is not established that leads to the separation as it is found from the response of the women. Further in the process of separation, half of them have to face courts whether it is initiated by husbands or wives. The dower and maintenance cost are the rights of women. But for the realization of that right the destitute women have to use the painful legal process. It is more unfortunate that their rights have not fully established by the court or society for the sake of financial inability of the separated husbands or other blame excuses. In the plight of such destitute women, they have to suffer for shelter and security. The loneliness is another great concern of these women. They become the subject of negligence in the society. The formal and informal support for these women is very insignificant. The financial, social and mental position of these women becomes weaker after these separations. The establishment of profit generating enterprises by these women is not successful. 
The supports in establishment of these enterprises are not available sufficiently from the NGOs or other organization. The destitute women did not get any kind of Govt. support. The social support is found as insignificant also. The attitudes of the working environment are not found supportive to them. The intention to remarry is not materialized for lack of social and individual support also. The support to these women in building up their enterprises is essential to lead their lives and their kids' future from the frustrated and painful lives.

\section{CONCLuSION}

The divorced women are the part of society and subject to all kinds of avoidance by Govt. and non Govt. institutions and society. The process of separation should be less hazardous and justified to ensure their rights. The social institutions should take pioneer role in the process of dissolution. The process of reconciliation should be emphasized more to reestablish the relationship. The rehabilitation of these destitute women in the society may results in economical, social and mental benefits to all. It is the imperatives of all concern to ensure justice to these women who are the victim of cruelty, greed of male counterpart or misunderstandings.

Limitations of the research: The sampling frame that confined in Sylhet area only is the main limitation of that study. The opinion of the male counterpart and experts are not collected to justify the mentioned reasons for separation. The opinions of the mediators are not considered also that may contribute in pinpointing the factors of failure in reestablishing the relationship and recovering the rights of women properly. The executives of institutions may contribute in finding out the reasons for not cooperating the destituteness and ways in proper cooperation. The reasons for failure in establishing profit generating business to support them and their kids are not established in that study.

Further Research: Expanding the sampling frame to generalize the findings is the key to further research. Besides, the opinion of male counterparts, experts, executives of supporting organizations are to be analyzed to pinpoint the problems of destitute women in rehabilitation program. The reasons for failure in establishing profit generating businesses are to be analyzed to protect them.

\section{REFERENCES}

Alam, Nurul. K. Saha Sajal, K and Jeron, K. Van Ginnekan (2000), Determinants of Divorce in a Traditional Muslim Society of Bangladesh, Demographic Research, Vol. 3, No. 4. Pp 75-78.

Ahmed N (2007), Divorced Women in Bangladesh Psycho-social and economic Conditions, Dhaka, AH Development Publishing House.

Bertrand Alvin L (1967), Basic Sociology, New York, Appleton-century-Crofts.

Chowdhury J N (1988), Divorce in Indian Society, Jaipur, India, Rupa Books.

Dorga Archana (1999), Marital Discord and Family Pathology - Impact on Children, New Delhi, HarAnand Publication Pvt. Ltd.

Fonseca Mabel (1966), Counseling for Marital Happiness, Bombay, Manaktala.

Hossain Naomi and Huda Samiha (1995), Problems of Women Headed Households, Working Paper 9, BARC-ICDDRB Joint Research Project, Dhaka

Johnson Hary M (1970), A Systematic Introduction, Bombay, Allied Publishers Pvt. Limited.

Marwalikar V K, Desetty R V and Patnam V N (2001), marital Separation and its Effect on Women, Social Welfare, Vol. 48 No 5, pp 11-14

Momen, Mehnaz, Bhuiya Abbas and Chowdhury Mushtaque (1995), Vulnerable of the Vulnerable: The Situation of Divorced, Abandoned and Widow Women in a Rural Area of Bangladesh, Working Paper 11, BARC-ICDDRB Joint Research Project, Dhaka

Nasir Rasheda Ireshad and Rezina Parvin Fathema (1996) Mahs- A Study on Marriage Payments Among the Urban Muslim Women, The Dhaka University Studies, Vol. 53 No1 pp93-105.

Pothen S (1986), Divorce, Its Cause and Consequence in Hindu Society, New Delhi, Vikas Publishing House Pvt. Ltd.

Rahman Tania (1996), Concept and Opinion of Dower, Dowry and Marriage Registration Among Middle Class Families in Dhaka City, Social Science Review, Part D, Vol. 12, No 2, pp 223-30.

Rahman Tania (1997), Marriage, Separation and Divorce Among Middle Class Families in Dhaka City, Social Science Review, Vol. 14, No 2, pp 13-28. 
Shahidullah M (1979), Differential Nuptiality pattern in Bangladesh, Development Studies Center, Canberra, Australian National University.

Shaikh Kashem (1998), The Social and Demographic Correlates of Divorce in Rural Bangladesh, Asia Pacific Population Journal, Vol. 13, No 3, pp 1-15.

Srivastava, Mannakshai and Priya (2002), Why Divorce? Famina Vol. 28, No 10, pp 8-14.

Velde Van De H (1976), Ideal Marriage: Its Physiology and Techniques, New Delhi, Allied Publishers Ltd.

Zaman M A (1990), Why Marriage Breakup? A Study on Divorce in Rural Bangladesh, Dhaka, USCanada-Bangladesh. 